\title{
Microsatellite characterization of Chital deer (Axis axis) by using faecal DNA
}

\author{
Kush Shrivastava, Mohan Singh Thakur, Shiv Nandan Singh Parmar, Avadh Bihari Shrivastav ${ }^{1}$ \\ College of Veterinary Science \& Animal Husbandry, MPPCVV, Jabalpur, M.P., India \\ 1. Center for Wildlife Forensic \& Health, MPPCVV campus, Jabalpur, M.P., India \\ Corresponding author: Kush Shrivastava, email:kush_vet@yahoo.co.in \\ Received: 14-06-2012, Accepted: 03-07-2012, Published online: 30-11-2012
}

\section{How to cite this article:}

Shrivastava K, Thakur MS, Parmar SNS and Shrivastav AB (2013) Microsatellite characterization of Chital deer (Axis axis) by using faecal DNA, Vet World 6(2): 83-86. doi: 10.5455/vetworld.2013.83-86

\begin{abstract}
Aim: To study the genome profile of Chital deer (A.axis) by microsatellite markers using faecal DNA \& to assess its usefulness as non invasive method of genotyping.

Materials and Methods: DNA was isolated from 44 animals from faeces and blood, out of which 26 (3 from blood and 23 from faeces) were subjected for genotyping. The PCR products of all the ten microsatellite loci were subjected to $6 \%$ UreaPAGE to differentiate allelic size.

Result: Total 57 alleles and 49 genotypes were found with their frequencies ranging from 0.022 to 0.457 and 0.043 to 0.696 respectively. The observed number of alleles ranged from $4-8,(A v .=5.7$ per locus). The PIC and Shannon's information index values for all loci ranged between 0.6645 to 0.8270 (Av. $=0.7442$ per locus) and 1.1870 to 1.8852 (Av. $=1.5122$ per locus) respectively.
\end{abstract}

Conclusion: Faecal DNA can be effectively used in genotyping wild animals, however the method and time of collection \& storage as well as the type of faecal material largely influences the quality \& quantity of DNA.

Key words: chital deer, faecal DNA, microsatellites, PIC, urea-PAGE

\section{Introduction}

Spotted deer or commonly called as "Chital" are one of the most common wild herbivore found in forests of India. The chital deer (Axis axis), also called the Indian spotted deer and the Axis deer, is native to India and Sri Lanka and does not have any special conservation status (Schedule III of Indian Wildlife Protection Act, 1972) and is listed as Least Concern (LC) in the IUCN Red List of threatened species [1]. Being so ubiquitous this deer species can act as a model organism for conservation genetic as well as wildlife forensic studies. Till date, there are very few studies on molecular genetics of chital deer in India. Recently, ten novel microsatellite markers were identified in chital deer and tested for their cross species amplification in other cervids in a captive population by Gaur et al. [2]. In the current study we used ten microsatellite loci, as described by Gaur et al. [2], in a free ranging, semicaptive population of chital deer. Microsatellites have become the genetic markers of choice for many kinds of molecular applications and they have found their extensive use in conservation biology too, including species identification [3], analysis of population structure [4] and dispersal patterns [5], to estimate genetic variability and inbreeding [6], for sex determination [7], for tracking alleles through a population [8] and individual identity and estimation of degree of relatedness between populations or pairs of individuals $[9,10]$.
Microsatellite marker provides an advantage in conservation studies as they are relatively easy to genotype and they require a very less amount of DNA that can be isolated from epithelial cells sloughed off in saliva [11], urine [12] or faeces [13]. Hence, non invasive techniques like utilizing faecal DNA to study the genetic architecture of wild animal population using microsatellite markers has become the backbone of conservation biology, these methods have found promising role in genetic monitoring [14], study of habitats [15], detection of rare and cryptic species [16], effect of human interventions on wild animal population [17] and genetic monitoring of founder population [18]. In this study we have targeted a semi captive population of chital deer which is found in a natural enclosure of a small protective area, the DNA was isolated from two sources, firstly from blood of the animals that were brought to the nearest wildlife center, Center for Wildlife Forensic and Health (CWFandH, Jabalpur) for treatment and from faeces of the animals collected from the protected area. Then, the appropriate DNA samples were subjected to microsatellite genotyping to study the genome profile and estimate the population genetic parameters of the targeted chital deer population.

\section{Materials and Methods}

Study area: Experimental material for this study comprised of DNA isolated from blood and faeces of 
Table- 1. Population genetic parameter for each microsatellite marker in studied chital deer (axis axis) population

\begin{tabular}{|c|c|c|c|c|c|c|c|c|}
\hline Locus & $\mathrm{T}_{\mathrm{a}}\left({ }^{\circ} \mathrm{C}\right)$ & Product Size (bp) & $\mathbf{K}$ & $n_{e}$ & $\mathrm{H}_{\mathrm{e}}$ & PIC & $\mathbf{I}$ & $\mathbf{F}_{\text {IS }}$ \\
\hline Ca13 & 58 & $210-252$ & 6 & 4.1654 & 0.7768 & 0.7599 & 1.5794 & -0.3159 \\
\hline Ca18 & 56 & $139-155$ & 5 & 3.6736 & 0.7440 & 0.7278 & 1.43 & -0.3740 \\
\hline Ca30 & 56.3 & $290-350$ & 4 & 3.0142 & 0.6831 & 0.6682 & 1.2111 & -0.4965 \\
\hline Ca38 & 57 & $215-250$ & 5 & 3.8755 & 0.7585 & 0.7420 & 1.4738 & -0.3478 \\
\hline Ca42 & 58 & $198-254$ & 8 & 5.7814 & 0.8454 & 0.8270 & 1.8852 & -0.2091 \\
\hline Ca43 & 61 & $255-300$ & 6 & 4.4083 & 0.7903 & 0.7732 & 1.6156 & -0.2934 \\
\hline $\mathrm{Ca} 60$ & 59 & $252-320$ & 8 & 3.8473 & 0.7565 & 0.7401 & 1.6133 & -0.3512 \\
\hline Ca67 & 55.4 & $189-222$ & 5 & 3.9925 & 0.7662 & 0.7495 & 1.491 & -0.3342 \\
\hline Ca71 & 64 & $261-310$ & 6 & 4.7658 & 0.8077 & 0.7902 & 1.6358 & -0.2656 \\
\hline Ca75 & 46.3 & $190-215$ & 4 & 2.9803 & 0.6792 & 0.6645 & 1.187 & -0.5050 \\
\hline Mean & & & 5.7 & 4.0504 & 0.7608 & 0.7442 & 1.5122 & -0.3319 \\
\hline St. Dev. & & & 1.4181 & 0.8223 & 0.0511 & 0.0500 & 0.2068 & 0.0796 \\
\hline
\end{tabular}

$\mathrm{T}_{\mathrm{a}}$ is Annealing temperature in ${ }^{\circ} \mathrm{C}, \mathrm{K}$ is number of alleles, ne is the effective number of alleles, He is expected heterozygosity, $\mathrm{F}_{1 \mathrm{~S}}$ is Wright's (1978) fixation index as a measure of heterozygote deficiency or excess, PIC is Polymorphic information content, I is Shannon information index.

chital deer, the samples were collected from CWFandH, Madhya Pradesh Pashu Chikitsa Vigyan Vishwa Vidyalaya (MPPCVV), Jabalpur, and Dumna Nature Reserve, Jabalpur, M.P., India.

Sample collection: The samples were collected within an hour of defecation, stored on ice then brought to the lab and stored at $-21^{\circ} \mathrm{C}$ and processed rapidly. DNA from total 44 chital deer was isolated out of which 26 DNA samples (3 from blood and 23 from faeces) showed optimum quality and quantity and were subjected for further genotyping.

DNA isolation: DNA isolation from blood was carried out by using method described by John et al. [19]. DNA from freeze dried faeces was isolated by using QIAamp DNA stool mini kit (Qiagen, Germany) as per manufacturer's instruction with little modifications. The modifications include, crusing the faeces in liquid nitrogen to make it finely powdered then adding double the amount of lysis buffer (supplied with kit) as well as addition of $0.5 \%$ Triton $\mathrm{X} 100$ and then incubation at $37^{\circ} \mathrm{C}$ for about $2-4 \mathrm{hr}$. in a water bath after thorough vortexing, and keeping the tubes in horizontal position for atleast $15 \mathrm{~min}$ with a little mixing in between during the addition of InhibitEX tablet. Proteinase K (25 $\mathrm{mg} / \mu \mathrm{l})$ was prepared fresh just before the DNA isolation.

Quality and quantity check of DNA: The DNA was subjected to $0.8 \%$ agarose gel electrophoresis to assess its quality; the concentration of DNA in samples was obtained from Nanodrop spectrophotometer (ND 1000). The average quantity of DNA from blood ranged from $250 \mathrm{ng} / \mu \mathrm{l}$ to $1220.7 \mathrm{ng} / \mu \mathrm{l}$ (OD 260/280 1.7-1.9), this DNA also served as a positive control, DNA from faeces was of relatively poor quality and quantity ranging from $25 \mathrm{ng} / \mu \mathrm{l}$ to $117 \mathrm{ng} / \mu \mathrm{l}$ (OD 260/280 - 1.6-1.8).

PCR amplification and urea denaturing PAGE: Ten primers specific for microsatellite loci in Chital deer as described by Gaur et al. [2] were used in the current study. A typical PCR cycle consisted of initial denaturation at $94^{\circ} \mathrm{C}$ for $10 \mathrm{~min}$., denaturation at $94^{\circ} \mathrm{C}$ for 30 s, annealing $46.3^{\circ} \mathrm{C}$ to $64^{\circ} \mathrm{C}$ for $30 \mathrm{~s}$, extension at $72^{\circ} \mathrm{C}$ for $1 \mathrm{~min}$. the cycle was repeated for 30 times, then final extension at $72{ }^{\circ} \mathrm{C}$ for $5 \mathrm{~min}$. The PCR products obtained were then subjected to $4 \%$ agarose gel electrophoresis for preliminary analysis and then on 6 $\%$ Urea - PAGE for size differentiation between the alleles [20]. The PAGE products were visualized by silver nitrate staining following the procedure of Gustavo and Gresenhoff [21].

\section{Results}

The microsatellite analysis was done using Popgene v1.32 [22]. Total 57 alleles and 49 genotypes were found with their frequencies ranging from 0.022 to 0.457 and 0.043 to 0.696 respectively. The observed number of alleles ranged from $4-8$, (Average $=5.7$ per locus). Maximum number of alleles i. e., eight were seen on loci Ca42 and Ca60. The PIC values for all loci ranged between 0.6645 to $0.8270(\mathrm{Av} .=0.7442$ per locus). The observed homozygosity was zero and the observed heterozygosity was one. Expected homozygosity and expected heterozygosity parameters varied between 0.1546 to $0.3208(\mathrm{Av} .=0.2392)$ and 0.6792 to $0.8454(\mathrm{Av} .=0.7608)$. The values of Shannon's information index were also calculated that ranged between 1.1870 to 1.8852 with an average of 1.5122 per locus (Table 1: Population genetic parameter for each microsatellite marker in studied chital deer (axis axis) population). $\mathrm{F}_{\mathrm{IS}}$ values ranged from -0.2091 to $0.5050(\mathrm{Av} .=-0.3319)$. Chi square value revealed that all the loci significantly $(\mathrm{P}>0.05)$ deviated from Hardy -Weinberg equilibrium.

\section{Discussion}

The results of gene and genotype frequency and heterozygosity parameters were found to be in concordance with those of Gaur et al. [2] in spotted deer. The heterozygosity level of microsatellite varies from species to species and sometimes within species. The heterozygosity and number of alleles determine its polymorphic information content and the polymorphic nature of microsatellite markers makes them marker of choice in characterization and genetic diversity studies. The PIC obtained in the present study was about 0.7442 per locus which was not significantly 
higher than those of certain other ungulates $(0.71$ in spotted deer [2], 0.81 in musk deer [23], 0.73 in forest musk deer [24]).

We did not detect a single homozygote in the current study which explains the negative $\mathrm{F}_{\text {IS }}$ values that are obtained and signifies an excess of heterozygotes in the population this might have occurred due to small sample size and scattered nature of the studied population. In the current study we utilized faecal DNA as the source for genotyping wild animals. Utilizing faecal DNA is advantageous as it is non invasive and does not require handling and restraining of wild animals. Sample storage and processing are the major factors determining the quality and quantity of faecal DNA $[25,26]$, however the season of collection also determines the quality [27], especially in Indian conditions, in general, samples collected in summer season showed a poor response to DNA isolation protocol. Non invasive genotyping is much easier in animals with bulk faeces like elephants [28], apes [29] and brown bears [30], but it is much more difficult in animals having pellet type of dry faeces like those of deer family.

\section{Conclusion}

In this study, we used DNA from two sources for microsatellite genotyping, blood and faeces. As expected, faecal DNA showed a poor quality and quantity, this might have occurred as we didn't used any preservative for faecal samples. Retention of faecal inhibitors is a common problem and hence multiple copies are to be set up in PCR. The microsatellite analysis revealed high degree of polymorphism among the studied loci in the targeted population. There was no homozygote individual found, it might be because the population is not entirely closed and there is continuous movement of animals in and out of protected area as well as the small population size included in the study. Faecal DNA can become a good source of genomic DNA in wild animals, although time of collection, type of preservative [31] used and processing steps do affect the quality and quantity of DNA.

\section{Author's contribution}

All authors contributed equally in the present study as well as in the preparation of manuscript. All authors read and approved the final manuscript.

\section{Acknowledgements}

We would like to take this opportunity to acknowledge the role of the authorities and staff of Dumna Nature Reserve, Jabalpur for providing necessary help in collection of faecal samples from the reserved area.

\section{Competing interests}

Authors declare that they have no conflict of interest.

\section{References}

1. Sankar K. and Acharya B. (2004). Chital (Axis axis (Erxleben, 1777)), ENVIS Bulletin, Wildlife Institute of
India, Dehradun 7: 171-180.

2. Gaur A., Singh A., Arunabala V., Umapathy G., Shailaja K. and Singh L. (2003). Development and characterization of 10 novel microsatellite markers from Chital deer (Cervus axis) and their cross-amplification in other related species, Mol. Ecol. Notes, 3: 607-609.

3. Adams J. R., Goldberg C.S., Bosworth W.R., Rachlow J.L. and Waits L.P. (2011). Rapid species identification of pygmy rabbits (Brachylagus idahoensis) from faecal pellet DNA, Molecular Ecology Resources, 11 (5): 808 - 812.

4. Hettinga P.N., Arnason A.N., Manseau M., Cross D., Whaley K. and Wilson P.J. (2012). Estimating size and trend of the North Interlake woodland caribou population using fecalDNA and capture-recapture models, The Journal of Wildlife Management, DOI: 10.1002/jwmg.380.

5. Kim G. Poole K.G., Reynolds D.M., Mowat G. and Paetkau D. (2011). Estimating mountain goat abundance using DNA from fecal pellets, The Journal of Wildlife Management, 75 (6): $1527-1534$.

6. McCarthy T.M., Waits L.P. and Mijiddorj B. (2009). Status of the Gobi bear in Mongolia as determined by noninvasive genetic methods, Ursus, 20(1): 30-38.

7. Vidal O., Pérez-Serra A. and Pla C. (2010). A sex determination protocol for the Iberian desman (Galemys pyrenaicus) based on a three primer amplification of DBX and DBY fragments with non-invasive samples, Conservation Genetics, 11(3): 1185-1187, DOI: 10.1007/ s10592-009-9913-1.

8. Luikart G., Biju-Duval M.P., Ertugrul O., Zagdsuren Y., Maudet C. and Taberlet P. (1999). Power of 22 microsatellite markers in fluorescent multiplexes for parentage testing in goats (Capra hircus), Anim Genet., 30: 431-438.

9. Michalski F., Valdez F.P., Norris D., Zieminski C., Kashivakura C.K., Trinca C.S., Smith H.B., Vynne C., Wasser S.K., Metzger J.P. and Eizirik E. (2011). Successful carnivore identification with faecal DNA across a fragmented Amazonian landscape, Mol Ecol Resour., 11(5): 862-871, Doi: 10.1111/j.1755-0998.2011.03031.x.

10. Dobigny T.R., Doan L.P., Quang N.L., Maillard J.C. and Michaux J. (2009). Species identification, molecular sexing and genotyping using non-invasive approaches in two wild bovids species: Bos gaurus and Bos javanicus, Zoo Biology, $28(2): 127-136$.

11. Inoue E., Inoue-Murayama M., Takenaka O. and Nishida T. (2007). Wild chimpanzee infant urine and saliva sampled noninvasively usable for DNA analyses, Primates, 48 (2): 156-159.

12. Valiere N. and Taberlet P. (2000).Urine collected in the field as a source of DNA for species and individual identification, Mol.Ecol., 9: 2149-2154.

13. Brinkman T.J., Person D.K., Chapin III F.S., Smith W. and Hundertmarka K. J. (2011). Estimating abundance of Sitka Black-Tailed deer using DNA from fecal pellets, J. Wildl. Manage., 75(1): 232 - 242.

14. Smith S., McRae P., and Hughes J. (2009). Faecal DNA analysis enables genetic monitoring of the species recovery program for an arid-dwelling marsupial, Australian Journal of Zoology 57(2): 139-148, Doi.org/10.1071/ZO09035.

15. Nogalesa M., Marreroa P, Padillaa D.P. and Medinaab F.M. (2009). The study of habitat use by censuses and molecular methods in birds: the case of two sympatric pigeons, Bird Study, 56 (3): 414-418.

16. Vine S.J., Crowther M. S., Lapidge S. J, Dickman C. R., Mooney N., Piggott M. P. and English A. W. (2009). Comparison of methods to detect rare and cryptic species: a case study using the red fox (Vulpes vulpes), Wildlife Research, 36(5): 436-446.

17. Karamanlidis A.A., Straka M., Drosopoulou E., Hernando M.G., Kocijan I., Paule L. and Scouras Z. (2012). Genetic diversity, structure, and size of an endangered brown bear population threatened by highway construction in the Pindos Mountains, Greece, European Journal of Wildlife Research, 
58 (3): 511-522.

18. Kruckenhauser L., Rauer G., Däubl B. and Haring E. (2009). Genetic monitoring of a founder population of brown bears (Ursus arctos) in central Austria, Conservation Genetics, 10 (5): 1223-1233, DOI: 10.1007/s10592-008-9654-6.

19. John S.W., Weitzner G., Rozen R. and Scriver C.R. (1991). A rapid procedure for extracting genomic DNA from leukocytes, Nucl. Acids Res., 19(2): 408.

20. Sambrook J. and Russel D.W. (2000). Molecular cloning : A Laboartory Manual. Vols. 1, 2, and 3. 3rd edn. Cold Spring Harbor, New York.

21. Gustavo C.A. and Gresshoff P. M. (1994). Staining Nucleic acid with silver: An alternative to radioisotopic and fluorescent labeling, Promega Notes Magazine, 45: p.13.

22. Yeh F.C., Yeng R.C., Timothy T.J.B., Ye Z.H. and Judy X.M. (1999). PROGENE 32 version 1.32, the user-friendly shareware for Population Genetic Analysis, Molecular Biology and Biotechnology centre, University of Alberta, Canada.http://www.ualberta.ca/ fyeh/popgene_download. html.

23. Xia S., Zou F., and Yue B. (2005). Six microsatellite loci in forest musk deer, Moschus berezovskii, Mol. Ecol. Notes, 6 : $113-115$.

24. Shu-chao Z, Bi-song Y., and Fang-dong Z. (2007). Isolation and characterization of microsatellite DNA markers from forest musk deer (Moschus berezovskii), Zoo. Res., 28 (1): 24-27.

25. Vynne C., Baker M.R., Breuer Z.K. and Wasser S.K. (2011). Factors influencing degradation of DNA and hormones in maned wolf scat, Animal Conservation, doi:10.1111/j.1469- 1795.2011.00503.x.

26. Stenglein J.L., De Barba M., Ausband D.E. and Waits L.P. (2010). Impacts of sampling location within faeces on DNA quality in two carnivore species, Molecular Ecology Resources, 10: 109-114.

27. Brinkman T.J., Schwartz M.K., Person D.K., Pilgrim K.L. and Hundertmark K.J. (2010). Effects of time and rainfall on PCR success using DNA extracted from deer fecal pellets, Conservation Genetics, 11(4): 1547-1552, DOI: 10.1007/ s10592-009-9928-7.

28. Ishida Y., Demeke Y., de Groot P.J.C., Georgiadis N.J., Leggett K.E.A., Fox V.E. and Roca A.L. (2011). Distinguishing Forest and Savanna African Elephants Using Short Nuclear DNA Sequences, J Hered., doi: 10.1093/ jhered/esr073.

29. Nsubuga A.M., Robbins M. M., Roeder A. D., Morin P. A., Boesch C., and Vigilant L.(2004). Factors affecting the amount of genomic DNA extracted from ape faeces and the identification of an improved sample storage method, Molecular Ecology, 13: 2089-2094.

30. Pérez T., Vázquez F., Naves J, Fernández A., Corao A., Albornoz J. and Domínguez A. (2009). Non-invasive genetic study of the endangered Cantabrian brown bear (Ursus arctos), Conservation Genetics, 10(2): 291-301,DOI: 10.1007/s10592-008-9578-1.

31. Michael Panasci M., Ballard W.B., Breck S., Rodriguez D., Densmore III L.D., Wester D.B. and Baker R.J. (2011). Evaluation of fecal DNA preservation techniques and effects of sample age and diet on genotyping success, The Journal of Wildlife Management, 75(7):1616-1624.

$* * * * * * * *$ 